\title{
Research on the Construction of Network Ecology of Ideological and Political Education in the New Period
}

\author{
Chao Wang ${ }^{1 \mathrm{a}}$ and Junzheng Wang ${ }^{2 \mathrm{~b} *}$ \\ ${ }^{1,2}$ Xincheng Street 2888, Jilin Agricultural University, Changchun, Jilin Province 130118, PR China

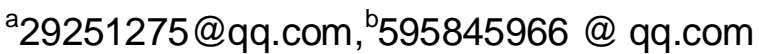 \\ the corresponding author: Junzheng Wang
}

Keywords: Ideological and political education; Network ecology; Construction

\begin{abstract}
At present, college students are the main body of ideological and political education, ideological and political education of college students is inseparable from the network, complex network ecology undoubtedly have an important impact on college students' ideological and political education. This paper further clarifies the relationship between the network ecology and the ideological and political education of college students, analyzes the shortcomings in the development of the ideological and political education network ecosystem, and puts forward the countermeasures to the ecological construction of the ideological and political education network.
\end{abstract}

\section{The Relationship between Network Ecology and Ideological and Political Education of College Students}

Ideological and Political Education and Network Ecology are Inseparable. Network ecology has a guiding role in ideological and political education, the main body of the network ecology, environment, carrier and legal norms and so on each factor affect the ideological and political education effect. First, ideological and political education is inseparable from the network ecology. The network ecology contains the internal environment and the external environment. In the external environment, through the Internet, the Western values, social thought spread into our high school, a great threat to ideology. In the internal environment, in the process of deepening the reform of the various social problems that affect the ideological ideas of college students. In this case, ideological and political education is inevitable and the network segmentation, in the context of network ecology to explore the ideological and political education of college students more oriented. Second, the development of network carrier for ideological and political education to build a new platform. With the popularity of Internet terminal communication tools, ideological and political education carrier development should also develop and use these platforms, the first time to master the ideological dynamics of college students, such as college students ideological and political education WeChat public number is a good carrier.

Ideological and Political Education Can Promote the Healthy Development of Network Ecology. The first reason is that college students are becoming the main network of Internet users. In the popularization of higher education today, college students as the main body of youth, they use the Internet to participate in the network ecosystem. The ideological and political education of college students can make the network ecology have a positive effect. Second, ideological and political education on the network of public opinion supervision and guidance plays an important role. If the ideological and political education of college students in the network of public opinion supervision and guidance if the play an active role, then they issued the information that the direction of the development of network ecology. As the network moral education of college students, psychological health education, help them establish a correct world outlook, outlook on life and values, discover the dynamic of college students' receive the good effect to promote the sound development of network ecology. 


\section{The Ideological and Political Education Network Ecosystem Development in the Shortcomings}

Ideological and Political Educators' Weaken and Lack of Discourse. The important reason for the weakening and deficiency of the discourse right of the ideological and political educators is that the educators lack the ability to obtain, analyze and use the media and the media information. Under the network ecology, college students use the network to obtain a lot of information, and ideological and political education of media literacy and lack of capacity. Internet public opinion information is changing, some educators from the network, which, so that the ideological and political educators have been digested and gradually weakened and missing. The decline of the authority of the educators, led to the plight of ideological and political education, at the same time, other network leaders to strengthen the right to speak, these network opinion leaders in the vast network of information, according to vulgar taste, to form their own point of view, get higher click rate and comments, eventually have a lot of fans. The ideological and political education of the remarks and the views of these leaders compared to the views of the way, do not pay attention to the way of expression of blunt views, often the lack of fans and listeners.

College Students are Vulnerable to the Impact of Network Damage. In a large number of network information there are many false, irrational content, which caused a strong impact on college students, resulting in many adverse consequences. First, the sense of morality weakened. Some netizens for some social events in the online personal views, the dissemination of false, irrational remarks, these false remarks and social ethics and ethics are related to the moral sense of college students had a shock. Such as "help or not help", "deceive donations" and other phenomena, which is a serious destruction of socialist moral construction, will encounter similar situations in college students, there will be " help or not help ", "donation or not donation" And other concerns, no doubt that college students become moral feelings of indifference. Second, interpersonal indifference. Some college students immersed in the network for a long time, weakened the actual participation in society, and the enthusiasm of others, resulting in interpersonal indifference. Third, the value of the judge to produce bias. The network of a large number of hype information and vulgar theme content impact of college students' values, individualism, money worship, hedonism and extravagant wind rampant, resulting in college students are not clear, good, beauty and false, ugly, evil, part of college students advocate decadent ideas and Western values, value judgments appear great deviations.

Network Ecological Construction Carrier Single: Colleges and universities can use the appropriate carrier to carry out the ideological and political education of college students lack of capacity, network construction of the carrier is lagging behind. Although there are some colleges such as Tsinghua University, Harbin Engineering University has established its own online education website, but most have not yet built the corresponding platform or do not make the platform play a role. Campus education website shoulder the important function of ideological and political education, but now play a small role. Such as the emergence of network public opinion on the campus, these sites can publish the relevant facts, to prevent public opinion fermentation, to guide public opinion to quell, for college students, these sites are relatively less attractive. Emerging media is more likely to be accepted by college students, such as QQ, microblogging, WeChat, etc., but these carriers are not very good use of colleges and universities, network ecological construction carrier is too single.

\section{The Countermeasures of Network Construction of Ideological and Political Education}

Strengthening the Subjectivity of Network Audience in Ideological and Political Education. First, enhance the ideological and political education network audience autonomy. The ideological and political education network audience is a college student, they face the complex information on the network, will be conscious of this information screening, and information on the conscious analysis, integration, should play its autonomy, so that they take the initiative to adjust their own Thinking and behavior, in accordance with their own quality and initiative to constantly improve 
themselves. The second is to enhance the influence of the ideological and political education audience. Network environment, college students have more information, the same can publish information. Therefore, in the network of ideological and political education, to respect and recognize the status of college students, to maximize their participation in educational activities initiative and influence.

Improve the Ideological and Political Education Network Audience and Communicator Literacy. First, improve the audience awareness of information literacy. At present, there are still some problems such as the lack of ability of using network information resources, the ability to screen and filter information, the awareness of network information security and the weak awareness of laws and regulations, which brings serious challenges to ideological and political education. To solve these problems, we must continue to cultivate college students keen sense of network information, enhance their ability to access, processing and network information, follow the network regulations, practice network ethics, and constantly enhance the network literacy of college students, consciously resist the impact of bad information, The Effectiveness of Network Ideological and Political Education. Second, attach great importance to the importance of network media literacy. Network media literacy education should focus on educating them to continuously improve the ability of analysis and evaluation, to correctly interpret the network information, consciously strengthen the theoretical level, enhance rational knowledge, improve media cognitive ability, and continuously improve the level of guidance in the process.

Focus on the Cultivation of Network Quality of Ideological and Political Educators. Ideological and political education in the network communication model plays an important role, a direct impact on the ideological and political education of the dissemination process and effect, so that their overall quality will directly affect the audience acceptance and educational results. Pay attention to ideological and political education of the network quality training, one is to strengthen the ideological and political education of the network literacy awareness. To play the guiding role of ideological and political education of the network, so that they change the concept of education, improve the role of positioning in the network to meet the information age of ideological and political education model. Second, the network of ideological and political education for specialized training, from the information concept, skills and other aspects of training, so that they fully aware of the important value of network information, attention to network information, grasp the pulse of thought, play a leading role. Focus on network skills training, familiar with the use of network operations, to explore the law of online education. The third is to effectively improve the overall quality of ideological and political education. With effective measures to make them face complex network environment with deep theoretical foundation, high political and moral quality, to keep calm mind, with a high degree of sensitivity and responsiveness, the network of various problem $\mathrm{s}$ identified, guide And finally solve and enhance the effect of ideological and political education on the network.

Focus on the Optimization of Network Environment of Ideological and Political Education. Network ideological and political education is inseparable from the environment, the network environment directly affects the ideological and political education activities of the process and effect. Because a college student is susceptible to the influence and infection of the network environment, the network environment contains a lot of resources, there are good and bad, which can guide the students' world outlook, outlook on life and values. Second, the network environment for the ideological and political education to provide places and conditions to create an educational atmosphere, to a large extent able to inspire the enthusiasm of the audience, affecting the efficiency of education. To sum up, to optimize the ideological and political education network environment, on the one hand is the negative factors in the network environment to resolve; the other is to give full play to the positive factors in the environment. The first is the audience to face the self-discipline of the network environment. Network virtual environment, a wide range of space, education can not be done from time to time supervision, a large part of the students to self-control, improve the environment conducive to their own development, refused to adverse environment. Second, we must continue to improve the network legislation. The optimization of the network 
environment can not leave the supervision and legal constraints, the Government through the development of network laws and regulations, increase illegal efforts to create a healthy network environment to ensure the healthy and orderly development of the network.

Paying Attention to Strengthening the Network Information Construction of Ideological and Political Education. Ideological and political education to enrich the ideological and political education content, in the production of content, in the form of gratifying to stimulate the audience's interest, consider the audience's ideological reality, innovative means of communication, enrich the educational content. First, we must continue to improve the attractiveness of network information. To avoid the form of a single content boring educational content, to the audience as the center, in the web design and content selection on a variety of forms, so that the audience easy to accept, happy to accept. Second, increase the technological content of information. For the needs of different audiences; the use of network multimedia technology to the appeal and artistic expression techniques, the use of modern scientific and technological information, to enhance the audience's emotional and rational understanding of information. The third is to innovate the form of network information, expand new space and new channels, promote the propaganda of ideological and political education content, expand coverage, carry out interactive programs, listen to the voice of college students, grasp the ideological situation and enhance the influence.

Strengthening the Interactive Communication between Ideological and Political Education Network. At present, the network of ideological and political education is not a one-way indoctrination model, passing both sides on an equal session, mutual respect, mutual learning, mutual influence is to carry out the correct way of ideological and political education in order to achieve the best educational results. First, to establish a harmonious, coordinated and interactive educational relationship. Effective communication needs to pass both sides respect each other, understand, trust, establish the concept of teachers and students democracy, a friend-style communication, for the audience, is to convince them to accept education and guidance. The second is to change the way and attitude. Change the educational methods, persuade people with the truth, with the feelings of people, in-depth understanding of the psychological changes in the audience, moving to love, dawn, so that the audience awareness to a certain height, to convince people to play the best educational effect.

Strengthening the Website and Platform Construction of Ideological and Political Education. Web sites and platforms as a network of ideological and political education carrier position, building a good, very good use. The current lack of such sites, and some are not close to the actual, content boring, resulting in click rate is not high, no appeal. It is imperative to build and use a number of popular and innovative schools for ideological and political education. First, to build close to the audience high-quality ideological and political education platform. Relying on the campus network and the corresponding platform, convenient and efficient and effective tools; close to the students, practical, for them to provide intimate personalized service. Subtle influence of ideological and political education through vivid examples of the audience to accept. Second, the use of existing other sites and platforms, such as BBS, and the audience to establish exchanges, interactive ties and bridges, to strengthen public opinion guidance and monitoring, to carry out online communication, good audience analysis and grooming work.

\section{References}

[1] Hu Qinxi. Network-based ideological and political education based on ecological perspective [J]. Journal of Kaifeng Institute of Education, 2014,34 (3): 213-214

[2] Liu Huajing. On the ideological and political education ecology of the five concepts [J]. Teaching and learning, 2009,11 (12): 57-59

[3] Li Zhaoyang, Zhang Yiwen. Preliminary study on the realization path of ecological value of network ideological and political education $[\mathrm{J}]$. contemporary educational theory and practice, 2013,05 (10): 138-140 
[4] Huang Jianping, Yang Zhifan. On the role of network ideological and political education environment and optimization [J]. Journal of University of Electronic Science and Technology of China (Social Science and Technology), 2007,9 (2).

[5] Lan Min. Internet environment under the ideological and political work of thinking [D]. Chongqing: Southwestern University of Finance and Economics of Master Thesis, 2004.

[6] Yan Tingting. Optimize the network environment, improve the ideological and political education effectiveness [J]. China Collective Economy, 2007.

[7] Wang Shanfei. Ideological and political education of College Students under network conditions [J]. Journal of Jiangsu Radio and TV University, 2005, 16:36-38.

[8] Liu Jing. Study on Rumor Management in the View of Network Public Opinion Ecology [J]. Information Science, 2014 (05).

[9] Han Qing, network public opinion ecological [J]. Western Broadcasting and Television, 2014 (05).

[10] Chen Xu Ling, Liu Jing. Network Politics: Informatization in the process of public domain derivatives [J]. Lanzhou Journal, 2007,1: 65-67.

[11]Meng Wei. Network communication in the language symbol variation [J]. Modern communication 2002,4: 89-91. 